\title{
Epidemiology of accidents involving venomous animals in the State of Ceará, Brazil (2007-2019)
}

\author{
Jacqueline Ramos Machado Braga ${ }^{[1]}$, Marta Maria Caetano de Souza ${ }^{[2]}$, \\ Iva Maria Lima de Araújo Melo ${ }^{[2]}$, Luis Eduardo Meira Faria ${ }^{[1]}$ \\ and Roberta Jeane Bezerra Jorge ${ }^{[3]}$
}

\author{
[1]. Universidade Federal do Recôncavo da Bahia, Centro de Ciências Agrárias, Ambientais e Biológicas, \\ Laboratório de Répteis e Anfíbios, Cruz das Almas, BA, Brasil. \\ [2]. Secretaria de Saúde do Estado do Ceará, Núcleo de Vigilância Epidemiológica, \\ Coordenadoria de Promoção e Proteção à Saúde, Fortaleza, CE, Brasil. \\ [3]. Universidade Federal do Ceará, Núcleo de Pesquisa e Desenvolvimento de Medicamentos, \\ Laboratório de Farmacologia de Venenos e Toxinas, Fortaleza, CE, Brasil.
}

\begin{abstract}
Introduction: Envenomation remains a neglected public health problem in most tropical countries. Epidemiological studies on accidents caused by venomous animals are scarce in the Northeast region of Brazil, mainly in the state of Ceará. The present study aimed to describe the epidemiological features of envenomation cases involving venomous animals in the State of Ceará, Northeastern Brazil, from 2007 to 2019. Methods: The online Notifiable Diseases Information System was consulted for data on all envenomation cases involving venomous terrestrial animals. Data collected were evaluated for the number of accidents/year, number of accidents/zoological group, antivenom therapy, zone of occurrence, sex, age-group distribution, and deaths. Results: A total of 54,980 cases were recorded, with the highest incidence being that of scorpion stings $(67.2 \%)$, predominantly in women $(52.4 \%$; odds ratio $=3.6 ; 95 \%$ confidence interval $=3.5-3.8)$, equally affecting people aged $10-19$ years and $40-59$ years $(21.4 \%)$, in the urban areas (odds ratio $=10.3 ; 95 \%$ confidence interval $=9.9-10.8)$, especially in the rainy months. Snakebites $(16.7 \%)$ had an incidence of 8.1/100,000 inhabitants, but the highest case-fatality rates were observed in bee stings (1.3\%) and spider bites $(0.5 \%)$. Regarding therapeutic variables, a small percentage of people had access to serotherapy (5.3\%). Conclusions: This study highlights the accidents caused by terrestrial venomous animals as a public health problem that must be monitored in Ceará. Thus, our findings suggest that preventive actions against scorpion and bee stings should be intensified during the months of higher incidence to improve public policies for patient care.
\end{abstract}

Keywords: Snakebite. Public health. Venom. Brazil.

\section{INTRODUCTION}

Due to the process of urban expansion, the shared spaces between humans and venomous animals are increasing, thereby increasing the risk of injuries ${ }^{1}$. Accidents caused by venomous animals occur frequently and represent a serious public health problem in tropical countries. Given this situation, permanent health surveillance actions should be implemented ${ }^{2}$.

\footnotetext{
Corresponding author: Dra. Jacqueline Ramos Machado Braga.

e-mail: jacquebraga@ufrb.edu.br

(iD) https://orcid.org/0000-0003-4417-8591

Received 20 July 2020

Accepted 13 November 2020
}

Data from the National Toxic-Pharmacological Information System (Sistema Nacional de Informação Tóxico-Farmacológica - SINITOX) reveal that venomous animals are the second-largest agent of human intoxication in Brazil. However, the lack of clinics, laboratories, and qualified technical staff contribute to the still high number of cases $^{2,3}$. Accidents caused by venomous animals, considered as a neglected condition in the world, are increasing every year ${ }^{4}$. In 2010 , accidents due to venomous animals was included in the compulsory disease notification list (LNC) in Brazil ${ }^{5,6}$. Despite the high numbers, the real magnitude of epidemiological data is still inconsistent in Brazil due to the high rate of underreporting and the omission of data while filling out the notification/investigation forms ${ }^{1}$. 
Accidents caused by venomous animals have a major impact on health as they compromise work activities, lead to socioeconomic damage, and impair the quality of life due to the possibility of sequelae and temporary or permanent disability. Thus, knowledge of the profile of the injury is essential to institute adequate vigilance in the prevention of cases and, consequently, deaths ${ }^{7}$. Epidemiological studies related to accidents involving venomous terrestrial animals are still very scarce in the state of Ceará. Considering this aspect, we aimed to describe the epidemiological profile of accidents caused by venomous animals that occurred in Ceará between 2007 and 2019.

\section{METHODS}

\section{Study area}

The state of Ceará, located in the Northeast region of Brazil, is composed of 184 municipalities, with a population of 9,132,078 inhabitants in 2019 , with approximately $75 \%$ living in urban areas 8 . Its territory covers an area of $148,894.7 \mathrm{~km}^{2}$ and it is located in the "Poligono da Seca," characterized by reduced rainfall, high temperatures, caatinga vegetation, and generally fine and salty soils ${ }^{8}$.

\section{Data collection}

This was a retrospective study to describe and analyze the epidemiological characteristics of cases of accidents caused by terrestrial venomous animals, using the Notifiable Disease Information System (SINAN) platform for collecting data covering the period from 2007 to 2019, available on the DATASUS website (SUS Department of Informatics, maintained by the Brazilian Ministry of Health) (Ministério da Saúde, 2019). These data were made available for us by Coodenadoria de Promoção e Proteção à Saúde/COVIG of the Ceará State Health Department. We used the following variables: sex, age-group distribution, zone of occurrence, month of occurrence, time from bite until assistance, antivenom therapy, deaths, and case evolution. Data on deaths caused by venomous animals were obtained from the Mortality Information System (Sistema de Informações sobre Mortalidade - SIM) using the search for death category ICD-10 (from external causes), grouped with the codes X20 (venomous snakes and lizards), X21 (spiders), $\mathrm{X} 22$ (scorpions), and X23 (bees).

\section{Ethics Statement}

Strict ethical and professional aspects were followed, maintained, and respected as established in the Resolution of the National Health Council no. 466 of December 12, 2012, which recommended that research involving only secondary data in the public domain, without nominal identification of the research participants, does not require analysis by a research ethics committee.

\section{Data analysis}

The data were compiled and tabulated to determine the simple frequencies (n) and relative frequencies (\%), and the results are presented in the form of contingency tables and graphs made using the Microsoft Excel 2016 program. The incidence, mortality, and case-fatality rates were also calculated. Demographic and population data from the Brazilian Institute of Geography and Statistics (IBGE) were used to calculate the incidence rates in Ceará for every 100,000 inhabitants. Fisher's test was used, and odds ratios (OR) were calculated to evaluate the association between the demographic variables and the venomous animal types involved in the envenomation?

\section{RESULTS}

In the state of Ceará, there was a marked increase in the number of accidents due to terrestrial venomous animals over the last decade, jumping from 1,492 cases in 2007 to 9,629 cases in $2019^{10}$. A total of 54,980 cases involving venomous animals were recorded between 2007 and 2019 in Ceará. Of these, 37,606 (68.4\%) were caused by scorpions, $9,193(16.7 \%)$ by snakes, $4,375(8.0 \%)$ by bees, $1,551(2.8 \%)$ by spiders, $362(0.7 \%)$ by caterpillars, and 1,272 (2.3\%) by other species (Figure 1).

The state of Ceará recorded the highest number of scorpion stings, ranging from 463 (2008) to 6529 (2019), followed by bee stings, ranging from 84 (2007 and 2008) to 1193 (2019), and snakebites, which ranged from 440 (2014) to 1039 (2019) (Figure 1).

Accidents caused by venomous animals occur throughout the year, following seasonal variations based on the aggressor species. In Ceará, the number of cases of scorpion stings increased from October to January, while envenomation incidents involving caterpillar and snake bites increased between June and July, and bee stings increased between August and September (Figure 2).

Throughout the historical series in Ceará, the total frequency of cases of envenomation involving women $(53.1 \%)$ was higher than the frequency of those involving men (46.9\%) (Table 1). On analyzing by the type of accident, the most frequently recorded in women were those caused by scorpion stings ( $81.2 \%)$, snakebites $(6.9 \%)$, and bee stings $(5.3 \%)$. The same animals also injured men more frequently: scorpions (53.9\%), snakes $(27.8 \%)$, and honeybees (10.9\%) (Table 1). An analysis of the association between sex (male and female) and the type of venomous animals showed that there was a higher chance of snakebites in males than in females $(\mathrm{OR}=5.2 ; 95 \%$ confidence interval $[\mathrm{CI}]=4.9-5.5 ; \mathrm{p}<0.05)$. A similar association was revealed with respect to bee stings $(\mathrm{OR}=2.1 ; 95 \% \mathrm{CI}=2.0-2.3 ; \mathrm{p}<0.05)$. As regards scorpion stings, there was a higher chance of it occurring in females than in males $(\mathrm{OR}=3.6 ; 95 \% \mathrm{CI}=3.5-3.8 ; \mathrm{p}<0.05)$.

Table 1 shows the cases distributed by age group, revealing that regardless of animal involvement, the majority of the cases recorded in Ceará occurred in the 29-34-year (35.5\%) and 40-59-year (25.6\%) age groups $(\mathrm{OR}=1.2 ; 95 \% \mathrm{CI}=1.19-1.33$; $\mathrm{p}<0.05)$. Spider bites $(\mathrm{OR}=1.2 ; \mathrm{CI} 95 \%=1.1-1.4 ; \mathrm{p}<0.05)$ and bee stings $(\mathrm{OR}=1.9 ; 95 \% \mathrm{CI}=1.7-2.0 ; \mathrm{p}<0.05)$ were higher in the 20-39-year age group. Considering the area of occurrence in Ceará (Table 1) during the study period, the highest frequency of cases was found in the urban area $(n=38,373 ; 71.9 \%)$ and was caused by scorpion stings $(\mathrm{n}=32,075 ; 83.6 \%)$; snakebites accounted for the largest number of cases in the rural area of Ceará $(n=7,085$; $48.1 \%)$. The rural zone showed greater probabilities of snakebites $(\mathrm{OR}=1.6 ; 95 \% \mathrm{CI}=1.5-1.7 ; \mathrm{p}<0.05)$, spider bites $(\mathrm{OR}=1.8 ; 95 \%$ $\mathrm{CI}=1.6-2.0 ; \mathrm{p}<0.05)$, and bee stings $(\mathrm{OR}=1.7 ; 95 \% \mathrm{CI}=1.6-1.8 ; \mathrm{p}$ $<0.05$ ), whereas the urban zone showed incidents involving mainly scorpions $(\mathrm{OR}=10.3 ; 95 \% \mathrm{CI}=9.9 .10 .8 ; \mathrm{p}<0.05)$. 


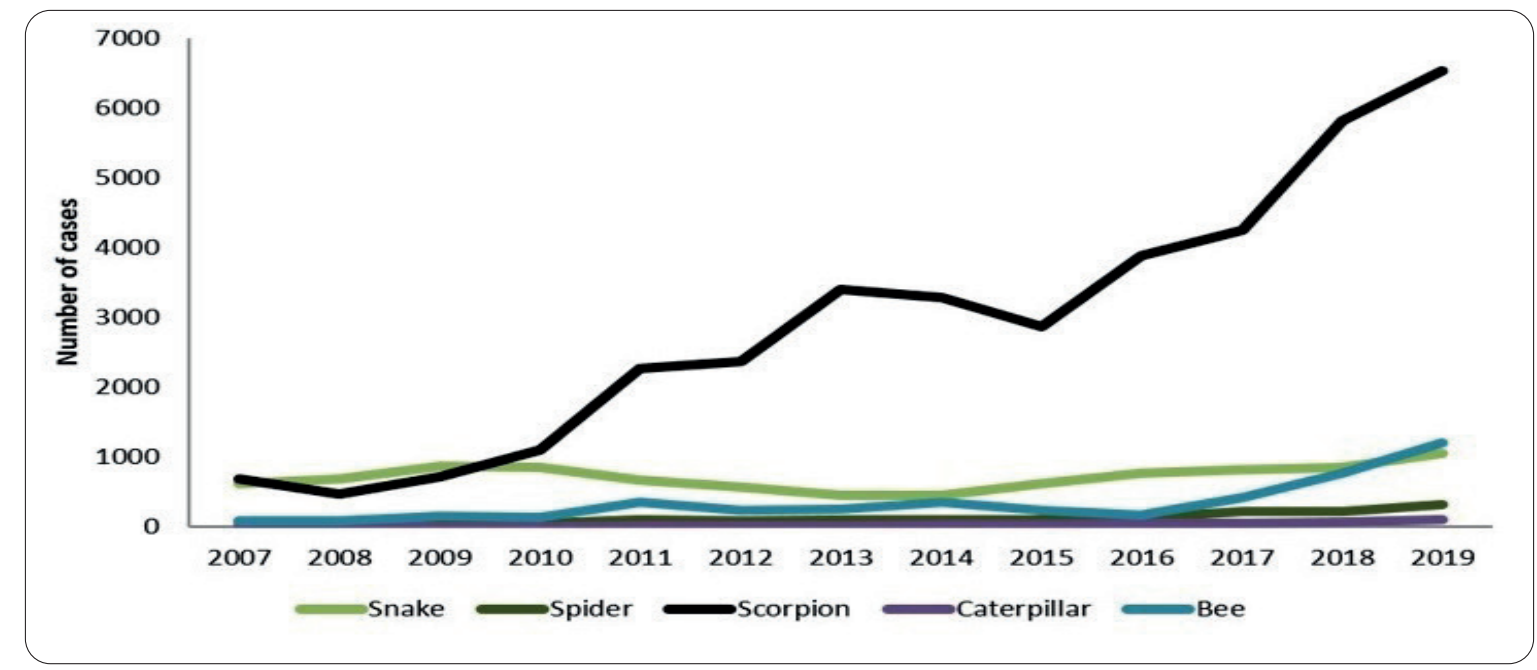

FIGURE 1: Temporal distribution of accidents involving venomous animals in Ceará, Brazil, from 2007 to $2019^{*}$. Source: Sesa/Nuvep/Sinannet, 2020. ${ }^{*}$ Cases in which the venomous animals were not identified were excluded.

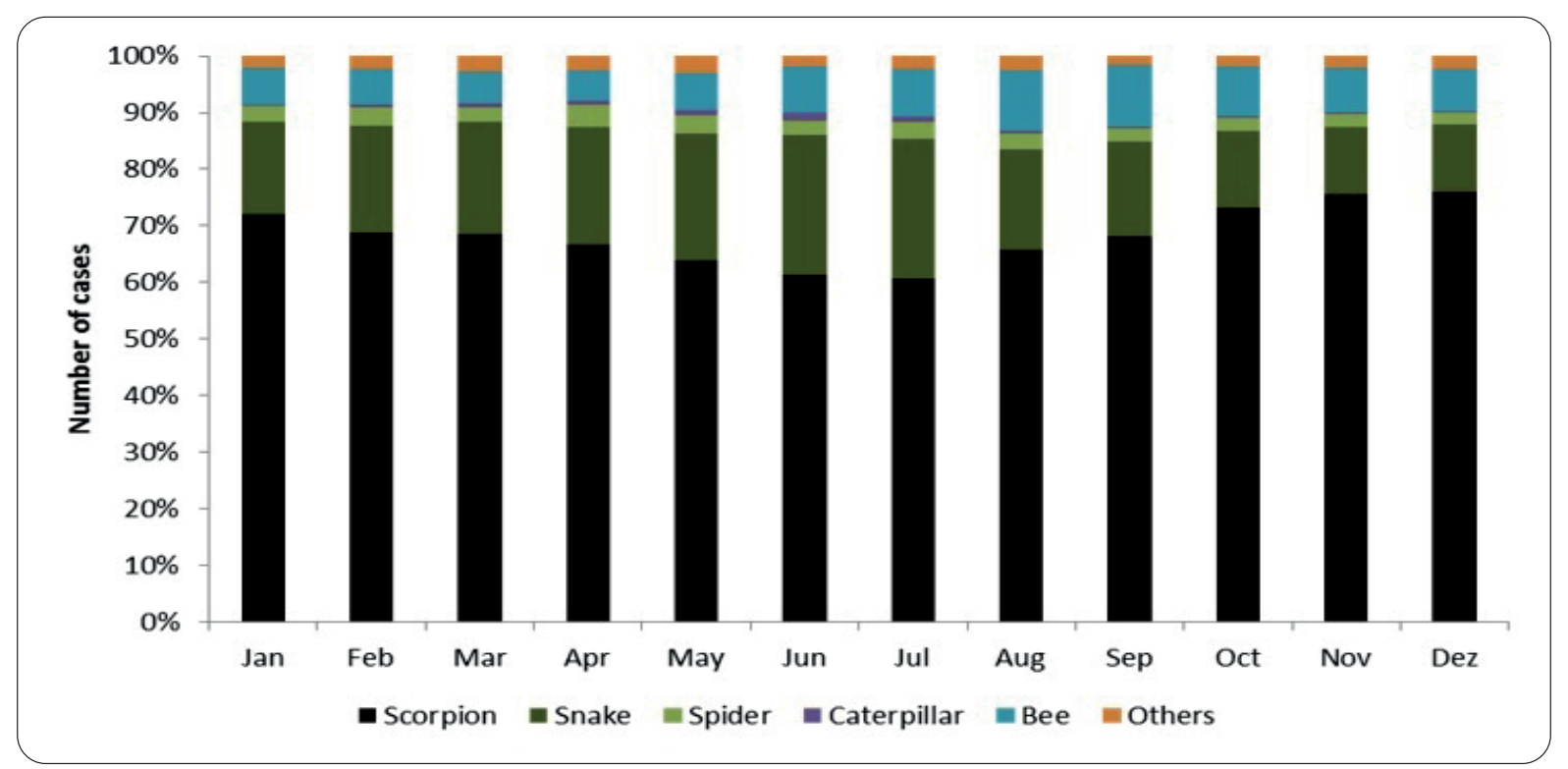

FIGURE 2: Seasonality of accidents caused by venomous animals, Ceará, Brazil 2007-2019*.

Source: Sesa/Nuvep/Sinannet, 2020. *Cases in which the venomous animals were not identified were excluded.

Scorpion bites had a higher incidence rate $(32.54 / 100,000$ inhabitants), ranging from 5.5 (in 2008) to 71.5 (in 2019). The incidence rate of snakebites was $8.1 / 100,000$ inhabitants, ranging from 5.1 (2013) to 11.4 (2019), followed by bee stings (3.79/100,000 inhabitants), which ranged from 1.0 (2008) to 13.1 (2019). The highest case-fatality rates were observed for bee stings $(0.04)$ and snakebites (0.03). However, the highest mortality occurred in the incidents caused by bee stings (1.9\%). For all the venomous animals, the average mortality rate was less than $0.1 \%$ and did not show significant changes between 2007 and 2019, regardless of the venomous species involved (Table 2). The majority of victims ( $\mathrm{n}=36,312 ; 66 \%)$ received medical assistance within $3 \mathrm{~h}$ after envenomation (Table 2).
As shown in Table 3, between 2007 and 2019, 54,980 incidents involving terrestrial venomous animals resulted in 88 deaths in Ceará, and the years $2019(\mathrm{n}=14 ; 15.9 \%)$ and $2009(\mathrm{n}=10 ; 11.4 \%)$ showed the highest number of deaths (data not shown).

The highest frequency of deaths was found among the cases caused by bee stings $(\mathrm{n}=50 ; 56.8 \%)$, snakebites $(\mathrm{n}=29 ; 32.9 \%)$, and spider bites $(n=7 ; 8 \%)$. The case evolution was not identified in 3,940 cases $(7.2 \%)$. Among all the cases described in the last 12 years, 523 were severe, mainly involving snakes $(\mathrm{n}=376)$ and bees $(\mathrm{n}=34)$. From 2007 to 2019, antivenom therapy was administered in Ceará in 9,328 (18\%) patients, and snakebites $(7,006 ; 75.1 \%)$ and scorpion stings $(1,863$; $20.0 \%$ ) were the cases that most frequently received antivenom therapy. 
TABLE 1: Sociodemographic data of registered cases of accidents caused by venomous animals in the state of Ceará (2007-2019)*

\begin{tabular}{|c|c|c|c|c|c|c|c|c|c|}
\hline \multirow{2}{*}{$\begin{array}{l}\text { Variables } \\
\text { Sex }\end{array}$} & \multicolumn{7}{|c|}{ Venomous animal } & \multirow{2}{*}{\multicolumn{2}{|c|}{ Total }} \\
\hline & \multirow[t]{2}{*}{ Unknown } & \multirow[t]{2}{*}{ Snake } & \multirow[t]{2}{*}{ Spider } & \multirow[t]{2}{*}{ Scorpion } & \multirow[t]{2}{*}{ Caterpillar } & \multirow[t]{2}{*}{ Bee } & \multirow[t]{2}{*}{ Others } & & \\
\hline & & & & & & & & 54,358 & 100 \\
\hline Male & & 7,184 & 729 & 13,912 & 165 & 2,823 & 660 & 25,800 & 46.9 \\
\hline Female & & 2,008 & 822 & 23,694 & 197 & 1,552 & 612 & 29,175 & 53.1 \\
\hline \multirow[t]{2}{*}{ Age range (years) } & & & & & & & & $\mathbf{n}$ & $\%$ \\
\hline & & & & & & & & 54,979 & 100 \\
\hline$<1$ & 10 & 109 & 29 & 551 & 10 & 66 & 27 & 802 & 1.5 \\
\hline $1-4$ & 37 & 191 & 62 & 2048 & 49 & 280 & 86 & 2,753 & 5.0 \\
\hline $5-9$ & 43 & 341 & 65 & 2044 & 37 & 317 & 96 & 2,943 & 5.4 \\
\hline $10-14$ & 45 & 657 & 83 & 2123 & 24 & 235 & 86 & 3,253 & 5.9 \\
\hline $15-19$ & 68 & 855 & 164 & 2984 & 21 & 371 & 98 & 4,561 & 8.3 \\
\hline 20-39 & 221 & 3,101 & 636 & 13,017 & 101 & 1,995 & 442 & 19,513 & 35.5 \\
\hline $40-59$ & 132 & 2,714 & 359 & 9,753 & 75 & 791 & 272 & 14,096 & 25.6 \\
\hline $60-64$ & 30 & 434 & 42 & 1,576 & 15 & 98 & 43 & 2,238 & 4.1 \\
\hline $65-69$ & 16 & 325 & 32 & 1,359 & 11 & 73 & 40 & 1,856 & 3.4 \\
\hline $70-79$ & 14 & 355 & 55 & 1,536 & 8 & 99 & 54 & 2,121 & 3.9 \\
\hline$\geq 80$ & 5 & 107 & 22 & 611 & 11 & 50 & 26 & 832 & 1.5 \\
\hline Unknown & 0 & 4 & 1 & 4 & 0 & 0 & 2 & 11 & 0.0 \\
\hline \multirow[t]{2}{*}{ Occurence area* } & & & & & & & & $\mathbf{n}$ & $\%$ \\
\hline & & & & & & & & 53,332 & 100 \\
\hline Urban zone & & 1,801 & 881 & 32,075 & 253 & 2,586 & 777 & 38,373 & 72.0 \\
\hline Rural zone & & 7,085 & 603 & 4,851 & 100 & 1632 & 445 & 14,715 & 27.6 \\
\hline Periurban & & 55 & 16 & 113 & 9 & 39 & 13 & 244 & 0.46 \\
\hline
\end{tabular}

*After excluding ignored questions and blank spaces. Source: Sesa/Nuvep/Sinannet, 2020.

\section{DISCUSSION}

Brazil is one of the countries with the most experience in the diagnosis and treatment of cases involving venomous animals. There are four notification systems for registering envenomations and case-fatality rates in the country. Currently, the SINAN is the most-used tool for analyzing these cases ${ }^{11,12}$, but SIM remains the most appropriate system for analyzing mortality data ${ }^{13,14}$.

The SINAN has recorded a progressive increase in the number of notifications involving venomous animals every year in $\mathrm{Brazi}^{4}$. Our data reveal an upward trend in the number of incidents involving venomous animals in Ceará. However, it is not possible to analyze whether there has been a real increase in the number of cases over the years or an improvement in the reporting system. This growth trend in cases involving venomous animals is corroborated by studies in other states in the Northeast Region, such as Rio Grande do Norte ${ }^{15}$, Paraíba ${ }^{2}$, and Piauí ${ }^{16}$.

Previous epidemiological studies have confirmed the influence of human and environmental factors on the occurrences of incidents involving venomous animals in Northeast Brazil ${ }^{17}$, especially in the rainiest months $\mathrm{s}^{15,16,18}$, corroborating our data. In our study, women were more vulnerable, and these results are in line with those of other epidemiological studies involving incidents caused by venomous animals in Brazil ${ }^{19}$ and in the Northeast region ${ }^{15,17,20-22}$. The predominance of men usually reveals their greater exposure to areas where there are risks of snakebites, and this is especially true for those performing manual civilian work, such as agricultural workers ${ }^{15}$. However, women and children are more exposed to scorpions, spiders, and caterpillars in the residential environment ${ }^{23}$.

Disorganized urban growth and industrialization, irrational use of natural resources, and ecological imbalance predispose the proliferation of venomous animals and promote overlap between the spaces used by humans and animals ${ }^{24}$. The increase in the population in Ceará probably impacted the occurrence of snakebites and scorpion stings, considering the increase in the volume of domestic waste ${ }^{15}$.

Previous studies in Ceará revealed a high incidence of scorpion bites that may have resulted from the high population density in the capital and from climatic conditions (high temperatures) and urban conditions (accumulation of waste and inadequate sanitation) that would facilitate the adaptation of scorpions to life in urban $\operatorname{areas}^{20}$. Thus, the implementation of educational programs for the prevention and treatment of envenomation by scorpions, offered to community and health agents, can be an effective measure of public policy to reduce the growing number of cases. 
TABLE 2: Epidemiological data of incidents involving venomous animals (snake, spider, honeybee, scorpion*, and caterpillar**), Ceará-Brazil, 2007 to 2019 ( $\mathrm{n}=54,980$ ).

\begin{tabular}{|c|c|c|c|c|c|c|c|c|c|}
\hline \multirow{3}{*}{$\begin{array}{l}\text { Variables } \\
\text { Time from bite until assistance (h) }\end{array}$} & \multicolumn{7}{|c|}{ Venomous animal } & & \\
\hline & Unknown & Snake & Spider & Scorpion & Caterpillar & Bee & Others & \multicolumn{2}{|c|}{ Total } \\
\hline & & & & & & & & $n$ & $\%$ \\
\hline & & & & & & & & 54,980 & 100 \\
\hline Unknown & 124 & 549 & 160 & 1,986 & 30 & 483 & 117 & 3,449 & 6.3 \\
\hline $0-1$ & 121 & 2,622 & 325 & 13,598 & 123 & 1,471 & 346 & 18,606 & 33.8 \\
\hline $1-3$ & 122 & 3,311 & 309 & 12,473 & 105 & 1,106 & 284 & 17,710 & 32.2 \\
\hline $3-6$ & 50 & 1,419 & 145 & 4,592 & 55 & 341 & 150 & 6,752 & 12.3 \\
\hline $6-12$ & 40 & 639 & 101 & 2,686 & 17 & 209 & 89 & 3,781 & 6.9 \\
\hline $12-24$ & 59 & 375 & 183 & 1,600 & 17 & 332 & 140 & 2,706 & 4.9 \\
\hline$\geq 24$ & 105 & 278 & 328 & 671 & 15 & 433 & 146 & 1,976 & 3.6 \\
\hline \multirow[t]{2}{*}{ Antivenom } & & & & & & & & $\mathbf{n}$ & $\%$ \\
\hline & & & & & & & & 51,894 & 100 \\
\hline Yes & 105 & 7,006 & 248 & 1,863 & 8 & 42 & 56 & 9,328 & 18.0 \\
\hline No & 469 & 2,617 & 1,201 & 32,996 & 328 & 3,847 & 1,108 & 42,566 & 82.0 \\
\hline \multirow[t]{2}{*}{ Case evolution } & & & & & & & & $\mathrm{n}$ & $\%$ \\
\hline & & & & & & & & 54,980 & 100 \\
\hline Unknown & 135 & 1334 & 213 & 1760 & 22 & 316 & 124 & 3,940 & 7.2 \\
\hline Cured & 484 & 7,816 & 1,326 & 35,822 & 340 & 4,049 & 1148 & 50,985 & 92.7 \\
\hline Death due to the notified condition & 0 & 29 & 7 & 2 & 0 & 50 & 0 & 88 & 0.2 \\
\hline Death due to another condition & 2 & 4 & 2 & 1 & 0 & 1 & 0 & 10 & 0.0 \\
\hline \multirow[t]{2}{*}{ Classification of case } & & & & & & & & $\mathbf{n}$ & $\%$ \\
\hline & & & & & & & & 54,980 & 100 \\
\hline Unknown & 157 & 779 & 139 & 1,002 & 17 & 270 & 95 & 2,459 & 4.5 \\
\hline Mild & 382 & 5,716 & 1,103 & 35,391 & 323 & 3,559 & 1080 & 47,554 & 86.5 \\
\hline Moderate & 72 & 2,322 & 288 & 1,137 & 22 & 512 & 91 & 4,444 & 8.1 \\
\hline Severe & 10 & 376 & 21 & 76 & 0 & 34 & 6 & 523 & 1.0 \\
\hline
\end{tabular}

Source: Sesa/Nuvep/Sinannet (2020) and SIM (2020) to death records. ${ }^{*}$ There were two deaths from scorpion bites in the historical series, resulting in zero mortality. and case-fatality rates. ${ }^{* *}$ There were no reported lethal cases involving caterpillars in the period.

TABLE 3: Epidemiological variables of registered cases of incidents involving venomous animals in the state of Ceará (2007-2019).

\begin{tabular}{|c|c|c|c|c|c|c|c|c|c|c|c|}
\hline \multirow[b]{2}{*}{ Year } & \multicolumn{3}{|c|}{ Snake } & \multicolumn{3}{|c|}{ Spider } & \multicolumn{3}{|c|}{ Bee } & \multirow{2}{*}{$\begin{array}{l}\text { Scorpion* } \\
\text { Incidence }\end{array}$} & \multirow{2}{*}{$\begin{array}{c}\text { Caterpillar* } \\
\text { Incidence }\end{array}$} \\
\hline & Incidence & Mortality & Lethality (\%) & Incidence & Mortality & Lethality (\%) & Incidence & Mortality & Lethality (\%) & & \\
\hline 2007 & 7.34 & 0.01 & 0.3 & 0.67 & 0.00 & 1.8 & 1.08 & 0.05 & 4.4 & 8.10 & 0.04 \\
\hline 2008 & 8.06 & 0.02 & 0.3 & 0.59 & 0.00 & 0.0 & 0.99 & 0.04 & 3.6 & 5.48 & 0.06 \\
\hline 2009 & 10.12 & 0.04 & 0.3 & 0.68 & 0.01 & 0.0 & 1.77 & 0.09 & 5.3 & 8.41 & 0.05 \\
\hline 2010 & 9.94 & 0.05 & 0.1 & 0.60 & 0.00 & 0.0 & 1.46 & 0.02 & 1.6 & 13.04 & 0.02 \\
\hline 2011 & 7.73 & 0.02 & 0.2 & 1.04 & 0.02 & 0.0 & 4.09 & 0.06 & 1.4 & 26.63 & 0.11 \\
\hline 2012 & 6.50 & 0.05 & 0.7 & 0.91 & 0.00 & 0.0 & 2.66 & 0.01 & 0.4 & 27.38 & 0.14 \\
\hline 2013 & 5.11 & 0.02 & 0.4 & 1.05 & 0.00 & 0.0 & 2.86 & 0.02 & 0.8 & 38.66 & 0.24 \\
\hline 2014 & 4.98 & 0.01 & 0.7 & 1.15 & 0.00 & 0.0 & 3.95 & 0.02 & 0.6 & 37.19 & 0.40 \\
\hline 2015 & 6.86 & 0.04 & 0.2 & 1.12 & 0.02 & 0.0 & 2.52 & 0.07 & 2.7 & 32.10 & 0.25 \\
\hline 2016 & 8.56 & 0.03 & 0.3 & 1.44 & 0.03 & 2.3 & 1.85 & 0.03 & 1.8 & 43.33 & 0.44 \\
\hline 2017 & 9.07 & 0.06 & 0.2 & 2.34 & 0.01 & 0.9 & 4.58 & 0.06 & 1.2 & 47.13 & 0.44 \\
\hline 2018 & 9.35 & 0.01 & 0.1 & 2.39 & 0.00 & 0.0 & 8.35 & 0.02 & 0.3 & 64.05 & 0.78 \\
\hline 2019 & 11.38 & 0.08 & 0.6 & 3.46 & 0.01 & 0.3 & 13.06 & 0.08 & 0.6 & 71.50 & 1.08 \\
\hline Average & 8.08 & 0.03 & 0.3 & 1.34 & 0.01 & 0.4 & 3.79 & 0.04 & 1.9 & 32.54 & 0.31 \\
\hline
\end{tabular}

Source: Sesa/Nuvep/Sinannet, 2020. ${ }^{*}$ There were no deaths during the study period. 
Mortality due to envenomation by venomous animals is due to the toxicity of the venom, the amount inoculated, and the precocity and effectiveness of the treatment administered to the victim ${ }^{25}$. Children, adolescents, and the elderly are more vulnerable to snakebites and scorpion stings, with higher case-fatality rates ${ }^{19}$. In previous studies conducted in Ceará, it was found that the majority of incidents involving venomous animals occurred in an urban areas ${ }^{15,20}$. Our data reveal that bee stings changed the epidemiological picture of Ceará, which shows the importance of studies with this venom and that of updating the notification data so that public policies can be directed to the injured. In previously sensitized people, a single sting of a hymenopteran insect, such as a honeybee, can result in rapid death ${ }^{26}$. However, even in non-atopic people, multiple stings can lead to death due to the higher dose of injected venom ${ }^{27,28}$.

In case of incidents involving venomous animals that occur in the rural areas of many tropical countries in Africa, Asia, New Guinea, and South America, there are difficulties in accessing conventional medical treatment in hospitals, due to delays in transporting the victim or because of the preference for treatment by local traditional healers ${ }^{28}$. Hospitalization occurs in moderate and critical cases that require specialized care due to their prolonged symptoms and the possibility of death ${ }^{29}$. An important factor to note is that most incidents involving venomous animals occur in regions that are far from referral hospitals (rural areas), and delayed care can aggravate cases, possibly resulting in systemic sequelae, the need for amputations, and even death of the victim in a few hours ${ }^{1}$. Such situations that result in death outside the health facilities are not entered in the notification records of the Ministry of Health. Thus, in most cases, the numbers do not portray the reality ${ }^{28}$.

Treatment time is associated with the severity of the envenomation; therefore, victims must have early access to medical care and antivenom therapy, thus resulting in better prognosis ${ }^{30,31,32}$. Studies carried out in the states of Bahia ${ }^{30}$ and Piaui ${ }^{33}$ showed an improvement in the information provided to the population about the urgency of medical assistance in these cases.

A previous study ${ }^{18}$ revealed that a total of 1,307 cases of bee stings were registered by Ceará in the SINAN, with only four deaths and a case-fatality rate of $0.3 \%$, a value well below that found in our study (1.9\%) using SIM death records. Such differences in the notifications of deaths may result from discrepancies in the updating of the mandatory notification systems (SIM and SINAN), which is a problem since SINAN identifies a marked increase in the number of deaths due to scorpion stings. The SIM shows a greater increase in the number of deaths due to bee stings, thus making it difficult to construct epidemiological scenarios ${ }^{34}$.

The underreporting of incidents involving venomous animals has been stated by several studies ${ }^{17,35}$. However, the increase in the number of cases over the years may reflect an improvement in the reporting system. Although Brazil has four national systems for recording, the information is still dissociated, resulting in data that may not represent the reality of this public health problem ${ }^{35}$. Thus, there is a need to analyze and periodically evaluate these notification systems, considering their strategic importance in decision-making in health service routines, public policies, and research ${ }^{34,36}$.
Up-to-date regional information is important for the development of epidemiological surveillance. A better understanding of the epidemiology of incidents caused by venomous animals in the state of Ceará should facilitate their prevention and management. Thus, more detailed studies are needed to clarify the clinicoepidemiological profile of envenomations, which will assist in the implementation of educational health care measures seeking to improve the assistance provided to victims.

\section{ACKNOWLEDGMENTS}

The authors express their gratitude to Coordenadoria de Vigilância em Saúde da Secretaria Estadual de Saúde do Ceará (COVIG/SESA/CE) and Núcleo de Vetores do Ceará (NUVET) for providing the epidemiological data.

\section{FINANCIAL SUPPORT}

Secretaria de Saúde do Estado do Ceará.

\section{AUTHORS' CONTRIBUTION}

MMCS and IMLAM conducted the survey and analysis of the data; LEMF performed statistical analysis and graphs; JRMB and RJBJ were involved in writing, edition, and improvement the manuscript. All authors discussed the final results and contributed to the final version.

\section{REFERENCES}

1. Machado C. Um panorama dos acidentes por animais peçonhentos no Brasil. J Health NPEPS. 2016;1(1):1-3.

2. Barbosa AR, Furtado CM, Cavalcanti MGS, De Lucena RFP. Análise das notificações de agravos por peçonhentos na região metropolitana de Campina Grande - Paraíba/Brasil - 2010/2015. Gaia Scientia. 2016;10(4):602-15.

3. Fiszon, JT, Bochner R. Subnotificação de acidentes por animais peçonhentos registrados pelo SINAN no Estado do Rio de Janeiro no período de 2001 a 2005. Rev Bras Epidemiol. 2008;11(1):114-27.

4. De Barros FCD, De Souza AR, Sousa KM. Perfil dos acidentes por animais peçonhentos no município de Caucaia - CE. In: Da Silva Neto BR, Ed.it. Saúde Pública e Saúde Coletiva: dialogando sobre interfaces temáticas. 5th ed. Ponta Grossa: Atena; 2019. p. 249-58.

5. Ministério da Saúde (MS). Portaria No 2.472, de 31 de Agosto de 2010. Available from: http://bvsms.saude.gov.br/bvs/saudelegis/gm/2010/ prt2472_31_08_2010.html.

6. De Souza W. Doenças negligenciadas. Academia Brasileira de Ciências, Rio de Janeiro. 2010;56 p.

7. Ministério da Saúde (MS). Secretaria de Vigilância em Saúde. Departamento de Vigilância Epidemiológica - Guia de Vigilância em Saúde. Brasília: MS. 2017;3:673-690.

8. Instituto Brasileiro de Geografia e Estatística (IBGE). População Estimada (2019). Available from: https://cidades.ibge.gov.br/brasil/ce/panorama

9. R Core Team. R: A language and environment for statistical computing. R Foundation for Statistical Computing, Vienna, Austria. 2019. Available from: https:/www.R-project.org/.

10. Ministério da Saúde (MS). Secretaria de Vigilância em Saúde. Sistema de Informação de Agravos de Notificação (SINAN) - Casos de acidentes por animais peçonhentos: Ceará (2007 a 2019). 2019. 
11. Ministério da Saúde (MS). Fundação Nacional de Saúde - Manual de procedimento do sistema de informações sobre nascidos vivos. Brasília: MS. 2001. 29p.

12. Bochner R. The international view of envenoming in Brazil: myths and realities. J Venom Anim Toxins Incl Trop Dis. 2013;19(1):29.

13. Laurenti R, Jorge MHPM, Gotlieb SLD. Estatísticas de mortalidade e seus usos. Reciis. 2013;7(2).

14. Bochner R. Sistema Nacional de Informações Tóxico-Farmacológicas (SINITOX): 35 anos de resistência. Reciis. 2016;10(1).

15. Albuquerque PLMM, Silva Junior GB, Jacinto CN, Lima CB, Lima JB, Veras MSB, et al. Epidemiological profile of snakebite accidents in a metropolitan area of Northeast Brazil. Rev Inst Med Trop Sao Paulo. 2013;55(5):347-51.

16. Da Cunha VP, Dos Santos RVSG, Ribeiro EEA, Maia Filho ALM, Marques RB. Perfil epidemiológico de acidentes com animais peçonhentos no Piauí. Revinter. 2019;12(1):76-87.

17. Da Costa MKB, Da Fonseca CS, Navoni JA, Freire EMX. Snake bite accidents in Rio Grande do Norte state, Brazil: epidemiology, health management and influence of the environmental scenario. Trop Med Int Health. 2019;24(4):432-41.

18. Diniz AGQ, Belmino JFB, De Araújo KAM, Vieira AT, Leite RS. Epidemiology of honeybee sting cases in the state of Ceará, Northeastern Brazil. Rev Inst Med Trop Sao Paulo. 2016;58.

19. Da Silva AM, Bernarde OS, De Abreu LC. Accidents with poisonous animals in Brazil by age and sex. Rev Bras Crescimento Desenvolv Hum. 2015;25(1):54-62.

20. Furtado SS, Belmino JFB, Diniz AGQ, Leite RS. Epidemiology of scorpion envenomation in the state of Ceará, Northeastern Brazil. Rev Inst Med Trop Sao Paulo. 2016;58:15.

21. Tavares AV, De Araújo KAM, Marques MRV, Vieira AA, Leite RS. The epidemiology of snakebite in the Rio Grande do Norte state, Northeastern Brazil. Rev Inst Med Trop Sao Paulo. 2017;59:e52.

22. Marques MRV, De Araújo KAM, Tavares AV, Vieira AA, Leite RS. Epidemiology of envenomation by Africanized honeybees in the state of Rio Grande do Norte, Northeastern Brazil. Rev Bras Epidemiol. 2020;23:E200005.

23. Lima JS, Martelli JH, Martelli DRB, Silva MS, Carvalho SFG, Canela JR, et al. Perfil dos acidentes ofídicos no norte do Estado de Minas Gerais, Brasil. Rev Soc Bras Med Trop. 2009;42(5):561-4.
24. Reis JRG, Ferreira SR, Andrade JHNB, Marafon ACF, Morraye MA Vigilância em Saúde Ambiental: interferência do ambiente na saúde humana em um município de Minas Gerais. Investigação. 2012;12(23):24-9.

25. Chippaux JP. Epidemiology of envenomations by terrestrial venomous animals in Brazil based on case reporting: from obvious facts to contingencies. J Venom Anim Toxins Incl Trop Dis. 2015;21:13.

26. Feitosa RF, Melo IM, Monteiro HS. The epidemiology of accidental bites by venomous snakes in the state of Ceará, Brazil. Rev Soc Bras Med Trop. 1997;30(4):295-301.

27. Arias TA, Go'mis VS, Mera ST, Castro AV, Gutiérrez JMV, Llamazares AA, et al. Key issues in hymenoptera venom allergy: an update. J Investig Allergol Clin Immunol. 2017;27(1):19-31.

28. Warrell DA. Venomous bites, stings, and poisoning: an update. Infect Dis Clin North Am. 2019;33(1):17-38.

29. Oliveira HFA, Costa CF, Sassi R. Relatos de acidentes por animais peçonhentos e medicina popular em agricultores de Cuité, região do Curimataú, Paraíba, Brasil. Rev Bras Epidemiol. 2013;16(3):633-43.

30. Santana CR, Oliveira MG. Avaliação do uso de soros antivenenos na emergência de um hospital público regional de Vitória da Conquista (BA), Brasil. Cien Saude Colet. 2020;25(3):869-78.

31. Mise YF, Lira-da-Silva RM, Carvalho FM. Time to treatment and severity of snake envenoming in Brazil. Brazil. Rev Panam Salud Publica. 2018;42: e52.

32. Secretaria da Saúde Ceará (SESA). Coordenadoria de Promoção e Proteção à Saúde - Boletim Entomológico: vigilância dos escorpiões. 2018. 13p.

33. Oliveira NR, Sousa ACR, Belmino JFB, Furtado SS, Leite RS. The epidemiology of envenomation via snakebite in the State of Piauí, Northeastern Brazil. Rev Soc Bras Med Trop. 2015;48(1):99-104.

34. Bochner R, De Souza CMV. Divergences between the Brazilian national information systems for recording deaths from venomous animals. J Venom Anim Toxins Incl Trop Dis. 2019;25:e143018.

35. Bochner R, Struchiner CJ. Acidentes por animais peçonhentos e sistemas nacionais de informação. Cad Saude Publica. 2002;18(3):735-46.

36. Carmo EA, Nery AA, Nascimento Sobrinho CL, Casotti CA. Clinical and epidemiological aspects of scorpionism in the interior of the state of Bahia, Brazil: retrospective epidemiological study. Sao Paulo Med J. 2019;137(2):162-8. 